\title{
Student Perceptions Towards Moodle and Kahoot Based e-Learning in Learning Mathematics
}

\author{
Ahmad Anis Abdullah ${ }^{1} *$, Tri Rochmadi ${ }^{2}$ \\ ${ }^{1}$ Department of Mathematics Education, ${ }^{2}$ Department of Information Systems, Universitas Alma Ata, Yogyakarta, Indonesia. \\ Telp. +62- 274- 434 2288. Email*: anis02108882@gmail.com
}

\begin{abstract}
Today's students are digital natives. They grow with digital technology. Universitas Alma Ata is adapting to learning styles in the digital age by integrating e-learning based learning and classroom learning. The e-learning model that is applied is based on moodle and kahoot. This learning model was introduced to students in September 2017. The meaning of this manuscript is to determine whether the use of moodle and kahoot based e-learning will help students in learning mathematics. It also examines the effect of applying elearning on student perceptions. Twelve mathematics education students were included in this study. A set of questionnaires was specified to evaluate students' attitudes and perceptions of learning. From the findings, conclusions have been drawn about the role of moodle and kahoot based e-learning to support the teaching and learning process. The results show that students show positive perceptions using moodle and kahoot based e-learning.
\end{abstract}

Keywords: Blended Learning, E-learning, Moodle, Kahoot, Mathematics Learning

\section{INTRODUCTION}

Technological developments are increasing rapidly in human life. The Internet has changed people's lifestyles, either from social, educational, health and even government (Rochmadi, et al. 2017). The presence of information technology has brought changes to students' learning patterns and styles. The higher education sector was initially based on manuals, demanding to be approved with the patterns and learning styles of students in the digital age. Smart universities are universities that are able to provide intelligent services and applications for students using the latest information technology (Coccoli et al. 2014). Supporting students become digital citizens. Digital citizens are citizens who have expertise, knowledge, internet, and access to the technology (Isman and Gungoren, 2014). School as a place to transfer knowledge, must provide basic knowledge for students in their live (Abdullah, 2017).

The development of technology also requires universities to develop distance education or what is called e-learning. E-learning is expected to be a solution to explore broader skills and knowledge that can be done anytime and anywhere using computer or smartphones. The development of technology also requires universities to develop distance education or what is called elearning. E-learning is expected to be a solution to explore broader skills and knowledge that can be done anytime and anywhere using a computer or smartphone (Iqbal and Ahmad, 2010). Distance learning method to seek knowledge without space and time (Qureshi et al. 2012). The e-learning system allows students to obtain various lecture materials, collect assignments through the website with the aim of supporting the teaching and learning process at the University. Universitas Alma Ata (UAA) develops classroom learning with e learning. Or better known as Blended Learning. With the help of technology, will Blended Learning (BL) make it easier for students to learn and can change their attitudes towards learning mathematics?

In students' computer programming courses, students are hope to able to master the programming fundamentals at the very beginning of their studies like structural and object-orientated programming design and programming languages $\mathrm{C}$ and $\mathrm{C}++$ for mathematic formula. This course have need sufficient time spent on the theory and practical lessons (depending on their preknowledge in this course (Richardo et al. 2019)), flexibly scheduled time will help for them to work on examples and exercises. BL will help for students because they have much time for to work their project.

$\mathrm{BL}$ is a formal education program in which a student learns at least in part through online delivery of content and instruction with some element of student control over time, place, path, and/or pace and at least in part at a supervised brick-and-mortar location away from home (Staker and Horn, 2012). Blended learning is an innovative concept that embraces the advantages of both traditional teaching in the classroom and ICT supported learning including both offline learning and online learning (Lalima and Lata Dangwal, 2017). It describes the development of a Blended Learning environment, which, in addition to classroom (face-to-face) lessons, introduces lessons delivered over the Internet (Djenic et al., 2011) 


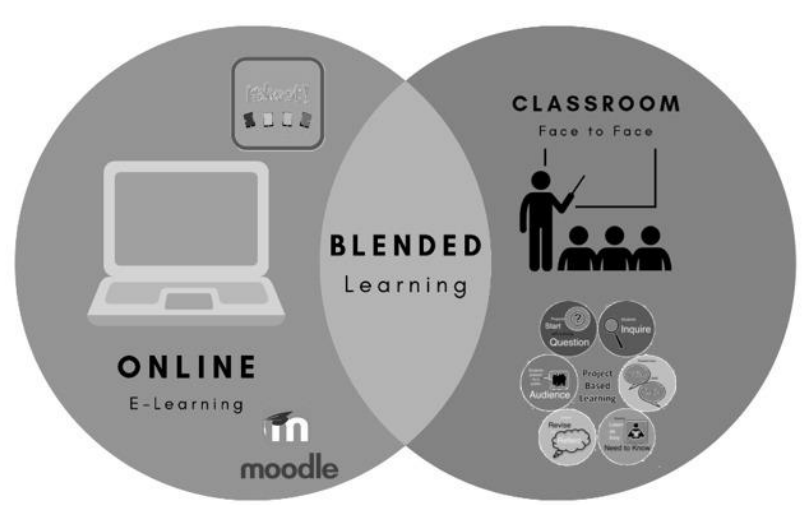

Figure 1. Blended learning in Universitas Alma Ata.

In the first year, the application of Blended Learning at the Universitas Alma Ata was carried out with 11 face-to-face sessions in the classroom and 3 meetings using e-learning. The e-learning concept is applied by using the moodle application for the delivery of material and kahoot for evaluation of learning through interactive quizzes. The e-learning system that contains the most widely used course management for distance education is Moodle (Modular Object-Oriented Dynamic Learning Environment). This moodle is a learning management system that is open source so that the system development can be done by the developer as needed. It also communicates extremely well with many web based resources (Facebook, YouTube, Wikipedia, JClik, Hot Potatoes, etc.), allowing developers creativity and versatility (Kotzer and Elran, 2012). Using Web services in Moodle allows lecturers and educators at different institutions to work together and share material by connecting individual courses together, which are hosted on different Moodle's. Therefore, 10 educators at different institutions can teach the same course and share activities such as assignments, chat, etc with each other (Al-Ajlan and Zedan, 2007). While Kahoot! is a free game-based learning platform for teachers and all learners (Repanovici et al., 2018). Kahoot! have some features that can use to play game, quiz, discussion and survey which to create competition through interactive games quiz (Lestari, 2019)

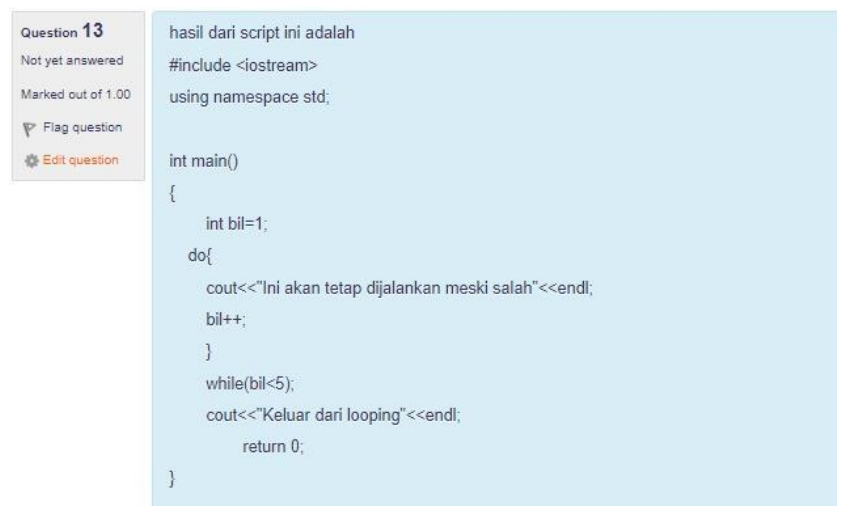

Figure 2. Page from the "quiz" test in e learning.

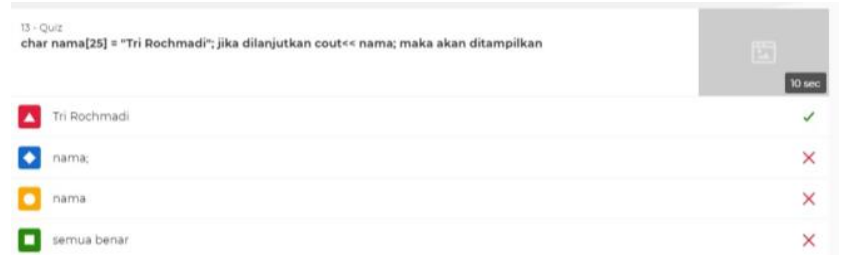

Figure 3. Page from the "quiz" test with Kahoot.

The purpose of this paper is to determine whether the BL approach which combines face-to-face learning in the classroom and e-learning based on Model and Kahoot will help students in computer programming courses at the UAA Mathematics Education Study Program. In addition, this paper examines the effect of the BL approach on students' perceptions of BL learning and find out the correlation between students' perceptions with midterm scores.

\section{MATERIALS AND METHODS}

This research is quantitative research. This paper examines the effect of the BL approach on students' perceptions of BL learning and finding out the correlation between students' perceptions with midterm scores. The study population was all Mathematics Education Students at Alma Ata University, which consisted of three classes. From the population, one class (one batch) is randomly sampled as a research sample, then the class gets learning with Blended Learning in computer programming courses. The instrument used to collect data was a set of questionnaire with 5 questions on perceptions and midterm. Responses to these questions are based on a Likert scale (1 strongly disagree to 5 strongly agree). The questionnaire was designed to show students' perceptions of BL. Meanwhile, to test the correlation between students' perceptions with midterm scores, data were analyzed using Bivariate Pearson Correlation. Benchmarks for the successful implementation of this study can be seen from the positive feedback on students 'learning in the questionnaire with on perceptions and the correlation coefficient between students' perceptions on BL and student midterm scores above 0.5 .

\section{RESULTS AND DISCUSSIONS}

As a result of the questionnaire, the use of $\mathrm{BL}$ in computer programming courses has positive feedback on students' learning, with the mean satisfaction score of 3.82. The overall results are given in Table 1 . The average mean for each item is between 3,39 and 4,15 out of 5 . 
Table 1. students' perceptions score of BL

\begin{tabular}{ll}
\hline Item & Score \\
\hline Are you easy to learn the topic using e learning & 3,39 \\
\hline $\begin{array}{l}\text { Learning became better using E learning and kahoot } \\
\text { compared to textbooks }\end{array}$ & 4,15 \\
\hline $\begin{array}{l}\text { E learning and kahoot make it easy to visualize } \\
\text { important concepts in mathematics }\end{array}$ & 3,62 \\
\hline $\begin{array}{l}\text { Happy with the concept of blended (lectures in class } \\
\text { and e learning) }\end{array}$ & 3,85 \\
\hline $\begin{array}{l}\text { Learning become more interesting with moodle and } \\
\text { kahoot }\end{array}$ & 4,08 \\
\hline
\end{tabular}

Furthermore, the average results of students' midterm exams reach 89,44 . The correlation coefficient between students' perceptions on BL and student midterm scores is 0,714 with a significance value of 0,006 at a significance level of 0,01 . These results indicate that the application of the Blended approach to computer programming courses has resulted in improved student performance. In addition, the use of kahoot for quizzes helps students learn at their own pace and motivates students to be winners in each quiz given by the lecturer. The majority of students indicated that learning became better and interesting using e-learning and kahoot compared to textbooks.

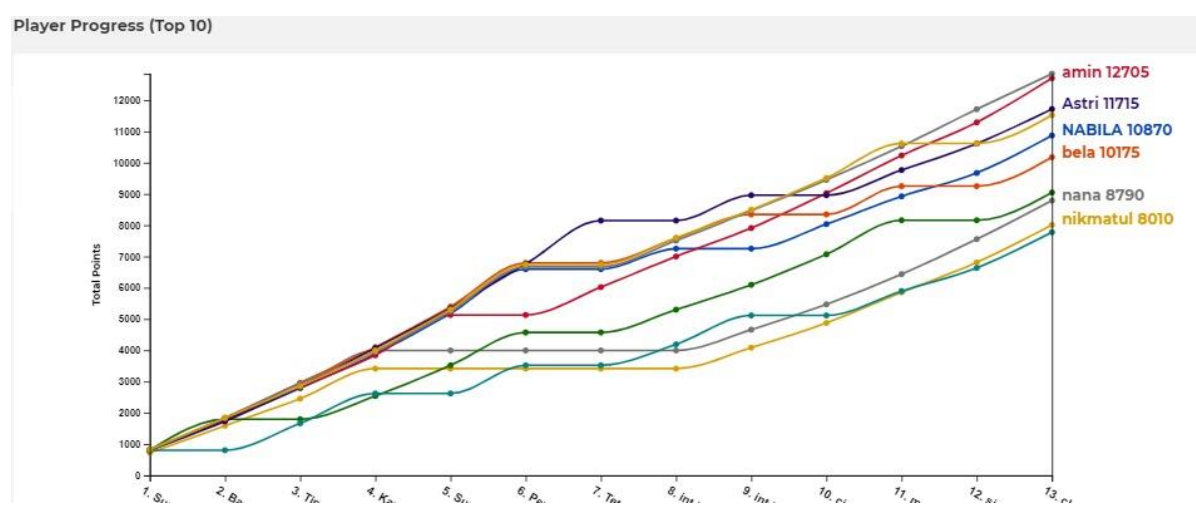

Figure 3. 10 of the best players in the kahooot quiz.

Based on the discussion above it can be concluded that technological developments are very influential in the field of education, especially in teaching and learning activities. This paper explains learning methods that combine face-to-face in the classroom and e-learning. Elearning with moodle for material delivery and discussion and kahoot for interactive quizzes as evaluation of learning. The results obtained from this study are students showing positive perceptions of learning. So the concept of blended learning can be applied in the mathematics education department to motivate students and increasing their test scores. Quiz with Kahoot encourages students to compete with each other to get the best player position. In addition, it is necessary to add online classes through e-learning, especially for practical subjects such as computer programming.

\section{CONCLUSION}

E-learning is no longer strange among students. in addition to making work easier, this system also allows one student to study together with others despite the distance. The use of Moodle and Kahoot is liked by many students. With Kahoot and Moodle, learning becomes more open and improves the quality of students with other students and with the outside world.

\section{REFERENCE}

Abdullah, Ahmad Anis. 2017. "Statistical Literacy For Beginner Voter." Proceedings of 1 st Ahmad Dahlan International Conference on Mathematics and Mathematics Education (8): 13-14.

Al-Ajlan, Ajlan, and Hussein Zedan. 2007. "E-Learning (MOODLE) Based on Service Oriented Architecture." Proceeding of the EADTU's 20th Anniversary Conference.

Coccoli, Mauro, Angela Guercio, Paolo Maresca, and Lidia Stanganelli. 2014. "Smarter Universities: A Vision for the Fast Changing Digital Era." Journal of Visual Languages and Computing 25(6): 1003-11.

Djenic, S., R. Krneta, and J. Mitic. 2011. "Blended Learning of Programming in the Internet Age." IEEE Transactions on Education 54(2): 247-54.

Iqbal, Muhammad Javed, and Mumtaz Ahmad. 2010. "Enhancing Quality of Education through E-Learning: The Case Study of Allama Iqbal Open University." Turkish Online Journal of Distance Education 11(1): 84-97.

Isman, Aytekin, and Ozlem Canan Gungoren. 2014. "Digital Citizenship." 13(1): 73-77. 
Kotzer, S., and Y. Elran. 2012. "Learning and Teaching with Moodle-Based E-Learning Environments, Combining Learning Skills and Content in the Fields of Math and Science \& Technology." 1st Moodle Research Conference: 14-15. http://research.moodle.net/55/1/16\%5Cn-

$\% 5$ CnKotzer\%5CnLearning\%5Cnand\%5Cnteaching\%5Cnwit $\mathrm{h} \% 5 \mathrm{CnM}$ Moodle-based\%5CnE-

learning.pdf\%5Cnhttp://research.moodle.net/55/1/16 - Kotzer - Learning and teaching with Moodle-based E-learning.pdf.

Lalima, Dr., and Kiran Lata Dangwal. 2017. "Blended Learning: An Innovative Approach." Universal Journal of Educational Research 5(1): 129-36.

Qureshi, Ijaz A., Khola Ilyas, Robina Yasmin, and Michael Whitty. 2012. "Challenges of Implementing E-Learning in a Pakistani University." Knowledge Management and ELearning 4(3): 310-24.

Repanovici, Angela, Ane Landoy, and Manolis Koukourakis. 2018. "Homework With Kahoot in Copyright Literacy."
Proceedings International Scientific Conference "Western Balkan Information Literacy": 36-41.

Richardo, Rino, Adhetia Martyanti, and Suhartini. 2019. "Developing Ethnomathematical Tasks in the Context of Yogyakarta to Measure Critical Thinking Ability." Journal of Physics: Conference Series 1188(1).

Rochmadi, Tri, Imam Riadi, and Yudi Prayudi. 2017. "Live Forensics for Anti-Forensics Analysis on Private Portable Web Browser." International Journal of Computer Applications 164(8): 31-37.

Staker, Heather, and Michael B. Horn. 2012. "Classifying K-12 Blended Learning.” Innosight Institute (May): 22. http://eric.ed.gov/?id=ED535180\%5Cnhttp://files.eric.ed.gov/f ulltext/ED535180.pdf.

Tika Wahyu Lestari. 2019. "Kahoot! And Quizizz: A Comparative Study On The Implementation Of E-Learning Application Toward Students' Motivation.” LinguA -LiterA 2(2): 13-22. 